\title{
KESIAPAN PERPUSTAKAAN DESA KERANO KUNCORO DALAM PENERAPAN SISTEM OTOMASI BERBASIS SENAYAN LIBRARY MANAGEMENT SYSTEM (SLiMS)
}

\author{
Lailatus Sa'diyah \\ Dosen Prodi Perpustakaan \& Sains Informasi FISIP UNIB \\ Email: lailasadiah@unib.ac.id \\ Purwaka \\ Dosen Prodi Perpustakaan \& Sains Informasi FISIP UNIB
}

\begin{abstract}
Abstrak:
Teknologi saat ini berkembang dengan pesat dan mempengaruhi aspek kehidupan manusia secara langsung maupun tidak langsung. Perpustakaan desa sebagai salah satu sumber serta pengelola informasi bagi masyarakat dituntut untuk mengikuti perkembangan teknologi informasi. Tujuan dari penerapan otomasi di perpustakaan adalah untuk mencapai kegiatan pengelolaan yang efektif dan efisien. Otomasi diharapkan dapat membantu pustakawan dalam menyelesaikan kegiatan administrasi menjadi lebih mudah dalam pengelolaan sehingga dapat memberikan layanan yang cepat dan tepat bagi pemakai perpustakaan. Penelitian ini menggunakan pendekatan kualitatif. Subyek penelitian ini adalah kepala perpustakaan dan petugas perpustakaan desa Kerano Kuncoro. Teknik pengumpulan data menggunakan data wawancara, observasi dan studi dokumentasi. Data yang diperoleh dianalisis secara kualitatif melalui tahap pengumpulan data, reduksi data, penyajian data dan penarikan kesimpulan. Hasil yang didapatkan adalah dari 6 aspek untuk penerapan sistem otomasi berbasis SLiMS, hanya 2 aspek yang masih kurang siap yaitu dalam aspek sumber daya manusia dan aspek prosedur. Sedangkan 4 aspek lainnya siap yaitu aspek perangkat keras, aspek perangkat lunak, jaringan, data dan database.
\end{abstract}

Kata Kunci: Perpustakaan Desa, Otomasi, SLiMS.

\begin{abstract}
:
Technology is increasingly developing and affecting aspects of human life directly or indirectly. The village library as one of the sources and information manager for the community required to always keep abreast of technology and information developments. Basically the purpose of library automation is to achieve effective and efficient management activities. Automation is expected to help librarians in completing administrative activities become easier in management so as to provide fast and appropriate services for library users. This research uses qualitative approach. The subjects of this research were the head of the library and the library officer of Kerano Kuncoro village. Data collection techniques use interview data, observation and documentation studies. The data obtained is analyzed qualitatively through the stages of data collection, data reduction, data presentation and conclusion drawing. From 6 aspects for the implementation of SLiMS, only 2 aspects are still underprepared, namely in the aspect of human resources and aspects of procedures. While the other 4 aspects are ready, namely the hardware aspect, software aspect, network, data and database.
\end{abstract}

Keywords: The village library, Automation, SLiMS.

\section{Pendahuluan}

Dalam UU No. 43 Tahun 2007 pasal 14 ayat 3 tentang layanan perpustakaan yang menyatakan bahwa setiap perpustakaan mengembangkan layanan perpustakaan sesuai dengan kemajuan teknologi informasi dan komunikasi. Pentingnya eksistensi perpustakaan dalam meningkatkan kecerdasan masyarakat tanpa memandang status sosial, ekonomi, agama, ras, dan budaya. Sejalan dengan hal di atas hendaknya penyedia jasa layanan informasi menyadari pentingnya informasi dalam rangka meningkatkan kualitas SDM ke arah yang lebih baik. Perkembangan teknologi informasi di perpustakaan saat ini telah berkembang dan sangat berpengaruh terhadap sistem layanan yang disediakan kepada pengguna perpustakaan. Salah satu perubahan teknologi yang paling menonjol dalam layanan perpustakaan adalah system automasi.

Sistem otomasi yang baik adalah yang terinte- 
grasi, mulai dari pengadaan, layanan, pengelolaan anggota, katalog online, serta adanya pengaksesan data dan informasi berbasis web dan internet. Sistem otomasi perpustakaan merupakan suatu sistem di dalam perpustakaan dengan memanfaatkan teknologi informasi yang mana setiap kegiatan dalam perpustakaan sudah terintegrasi, sehingga sistem otomasi perpustakaan sering disebut juga dengan sistem perpustakaan terintegrasi atau integrated library system. Perpustakaan desa sebagai pengelola informasi harus berkembang dengan kemajuan teknologi yang ada. Pada dasarnya tujuan dari otomasi perpustakaan adalah untuk mencapai kegiatan pengelolaan yang efektif dan efisien. Otomasi diharapkan dapat membantu pustakawan dalam menyelesaikan kegiatan administrasi menjadi lebih mudah dalam pengelolaan sehingga dapat memberikan layanan yang cepat dan tepat bagi pemakai perpustakaan.

Perpustakaan Desa Kerano Kuncoro merupakan perpustakaan desa di Desa Sri Kuncoro yang telah mempunyai ruangan tersedniri walaupun masih kurang memadai. Selain itu, di perpustakaan ini masih menggunakan sistem manajemen perpustakaan secara manual dan belum berbasis otomasi dan ketersediaan komputer masih sebatas untuk inventarisasi saja. Perpustakaan yang diidentikkan dengan bangunan yang lama, buku-buku lama, suasana yang sunyi. Hal tersebut sering dikatakan perpustakaan tradisional. Untuk merubah cara pandang masyarakat mengenai perpustakaan ada beberapa konsep yang harus diterapkan di perpustakaan salah satunya lebih ditekankan kepada model manajemen perpustakaan dengan pengaplikasian teknologi informasi dan komunikasi yang modern.

\footnotetext{
Fandirwan, Penerapan SLiMS (Senayan Library Management System) Di Perpustakaan AKPER/AKBID Pelamonia Kesdam VII/Wirabuana Makassar, 2015.

${ }^{2}$ Mahedy, Kadek Surya, Implementasi Otomasi Layanan Perpustakaan dengan SLiMS Di Perpustakaan UNDIKSHA, 2015.

${ }^{3}$ Sulistyo-Basuki, Pengantar Ilmu Perpustakaan, (Jakarta: Gramedia Utama, 2017)
}

Fenomena yang dipaparkan di atas yang kemudian menjadi landasan peneliti untuk melakukan penelitian mengenai kesiapan perpustakaan desa dalam penerapan sistem otomasi. Bagaimana kesiapan Perpustakaan Desa Kerano Kuncoro dalam Penerapan Sistem Otomasi berbasis SliMS.

\section{Penelitian Terdahulu}

Adapun beberapa penelitian terdahulu yang relevan dengan permasalahan penelitian yang dikaji peneliti saat ini yaitu:

1. Penelitian yang berjudul Penerapan SLiMS (Senayan Library Management System) di Perpustakaan AKPER/AKBID Pelamonia Kesdam VII/Wirabuana Makassar. Penelitian ini bertujuan untuk mengetahui penerapan dan kendala penerapan SLiMS di Perpustakaan AKPER/AKBID Pelamonia Kesdam VII/ Wirabuana Makassar. Hasil penelitian di dapatkan bahwa penerapan SLiMS belum optimal dengan beberapa kendala yang dialami oleh perpustakaan. ${ }^{1}$

2. Penelitian yang berjudul Implementasi Otomasi Layanan Perpustakaan dengan SLiMS di Perpustakaan UNDIKSHA. Penelitian ini merekomendasikan sebuah perangkat lunak perpustakaan digital berbasis open source yang diharapkan menjadi alternative pemberian layanan untuk mengatasi kendala-kendala dalam akses informasi di perpustakaan, proses pelayanan perpustakaan dan kearsipan secara manual. ${ }^{2}$

Hubungan penelitian di atas dengan peneliti adalah peneliti ingin melihat penerapan system otomasi di perpustakaan. Analisis penelitian ini menggunakan teori komponen system otomasi,

${ }^{4}$ Pendit, Putu L, Perpustakaan Digital dari A sampai Z.,(Jakarta: Cipta Karya Karsa, 2008)

${ }^{5}$ Arif, Ikhwan, Makalah seminar dan workshop sehari dengan judul "Membangun jaringan perpustakaan digital dan otomasi menuju masyarakat berbasis pengetahuan". UMM 4 Oktober 2013. (http:aurajogja. wordpress.com/2006/07/11/otomasi perpustakaan. Didowload pada tanggal 2 Februari 2020). 
peneliti memilih teori tersebut karena dianggap sesuai dengan penelitian mengenai kesiapan dalam penerapan system otomasi berbasis SLiMS.

\section{Tinjauan Pustaka}

\section{a. Otomasi Perpustakaan}

Menurut Sulistyo-Basuki, bahwa otomasi adalah "Penerapan teknologi informasi untuk kepentingan perpustakaan mulai dari pengadaan, hingga ke jasa informasi bagi pembaca, yang mencakup proses membuat mesin swatindak atau swakendali dengan menghilangkan campur tangan manusia pada proses tersebut. ${ }^{3}$ Kemudian menurut Pendit, memberikan definisi otomasi perpustakaan adalah seperangkat aplikasi komputer untuk kegiatandi perpustakaan yang mempunyai ciri penggunaan pangkalan data ukuran besar dengan fasilitas utama dalam hal menyimpan, menemukan dan menyajikan informasi. ${ }^{4}$

Dari definisi di atas dapat disimpulkan bahwa otomasi perpustakaan sebagai sebuah penerapan teknologi informasi di perpustakaanberupa komputer dan aplikasinya dengan tujuan untuk memudahkan pengelola perpustakaan dalam pengolahan, penyajian dan pelayanan informasi kepada para pengguna.

\section{b. Komponen Otomasi Perpustakaan}

Dalam penerapan otomasi perpustakaan ada beberapa komponen yang diperlukan untuk mendukung kelancarannya. Menurut Arif, komponen atau unsur otomasi meliputi pengguna (user), ${ }^{5}$ perangkat keras (hardware), perangkat lunak (software), network/jaringan, data dan prosedur. Dalam uraian berikut akan dijelaskan satu persatu mengenai komponen otomasi perpustakaan tersebut:

${ }^{6}$ Rahayuningsih, F, Pengelolaan perpustakaan., (Yogyakarta: Graha Ilmu, 2007).

${ }^{7}$ Arif, Ikhwan, op.cit.

8Rahayuningsih, F, op.cit. a) Pengguna (user)

Unsur utama dalam penerapan otomasi perpustakaan adalah pengguna. Salah satu unsur utama yang perlu diperhatikan dalam melaksanakan komputerisasi perpustakaan adalah sumber daya manusia, yaitu petugas perpustakaan yang mengopersaikan sistem komputer, dan petugas perpustakaan yang bertanggung jawab atas pemilihan dan pemeliharaan sistem komputer, serta pemeriksaan aplikasi apakah sudah sesuai dengan kebutuhan dan komputer yang digunakan. ${ }^{6}$

b) Perangkat keras (hardware) Perangkat keras dalam hal ini adalah sebuah komputer dan alat bantu lainnya seperti printer, barcode, scanner dan lainnya.

c) Perangkat lunak (software)

Perangkat lunak yang dimaksud adalah sebuah metode atau prosedur untuk mengoperasikan komputer agar sesuai dengan permintaan pemakai. Kecenderungan dari perangkat lunak mampu diaplikasikan dalam berbagai sistem operasi, mampu menjalankan lebih dari satu program dalam waktu bersamaan, kemampuan mengelola datayang lebih handal, dapat dioperasikan secara bersama atau multi- user. ${ }^{7}$

d) Jaringan

Jaringan komputer telah menjadi bagian dari otomasi perpustakaan untuk mempercepat akses informasi dan data. Dalam hal ini dalam membangun jaringan komputer diperlukan adanya jumlah komputer yang memadai serta luas lingkup dari jaringan tersebut.

e) Data

Data yaitu informasi, fakta, dan angka-angka yang diolah oleh komputer menjadi informasi digital dan disusun menjadi basis data, misalnya basis data koleksi, anggota, dan pengunjung perpustakaan. ${ }^{8}$

f) Prosedur

Prosedur adalah penjelasan bagaimana memasang, menyesuaikan, menjalankan suatu perangkat keras dan lunak. 


\section{Metode Penelitian}

Penulis memilih dan menggunakan metode pendekatan kualitatif. Lokasi penelitian ini adalah Perpustakaan Desa Kerano Kuncoro, Bengkulu Tengah. Dalam penelitian ini, peneliti menetapkan pihak-pihak yang menjadi sumber data penelitian yang terdiri ini adalah kepala perpustakaan dan 1 tenaga perpustakaan di bagian IT.

Teknik pengumpulan data dilakukan dengan metode wawancara, metode observasi dan metode dokumentasi.

\section{Hasil dan Pembahasan}

Penerapan sistem otomasi berbasis SLiMS merupakan upaya pengembangan pengelolaaan perpustakaan desa guna mengimbangi laju pesatnya perkembangan teknologi informasi. Penerapan SLiMS di perpustakaan desa diharapkan mampu mendorong tumbuhnya motivasi masyarakat desa untuk selalu memanfaatkan sumber yang ada di perpustakaan sehingga minat baca masyarakat dapat tumbuh dan berkembang. Tentu saja dalam penerapan SLiMS ini sangat membutuhkan kesiapan dari perpustakaan desa dari berbagai komponen pendukungnya.

\section{a) Kesiapan Pengguna}

Sumber daya manusia adalah salah satu faktor kunci keberhasilan penerapan SLiMS. Jumlah tenaga perpustakaan di Perpustakaan Kerano Kuncoro sebanyak 10 orang. Penerpan SLiMS di perpustakaan desa ini merupakan rintisan pengembangan perpustakaan dari perpustakaan daerah Provinsi Bengkulu. Dalam hal ini bantuan berupa pembimbingan/pelatihan kepada tenaga perpustakaan terkait teknis penerepan SLiMS. Berdasarkan hasil wawancara dengan kepala perpustakaan, menyatakan bahwa:

"Ada, perpustakaan bekerjasama dengan perpusda provinsi"

Kemampuan tenaga perpustakaan dalam memahami dan mengaplikasikan software merupakan modal utama untuk keberhasilan penerapan system otomasi berbasis SLiMS. Saat ini petu- gas perpustakaan yang mengoperasikan SLiMS hanya 2 orang. Upaya perpustakaan dalam penyiapan SDM adalah dengan belajar dari Perpusd Prov. Bengkulu dan anak-anak Himataksifo UNIB. Hambatan dalam penerapan SLiMS di Perpustakaan Desa Kerano Kuncoro terbatasnya pengetahuan petugas dalam mengoperasikan SLiMS. Berdasarkan hasil wawancara dengan petugas perpustakaan dan kepala perpustakaan menyatakan bahwa:

"Program yang digunakan pertama kali tahun 2019 adalah senayan, sekarang tetap senayan tapi versi yang 9. Yang mengelola SLiMS sehari-hari hanya saya dan mbak Yuli."

"Upaya perpustakaan untuk menyiapkan SDM pengelola yang menguasai SLiMS hanya sekedarnya, belajar dari perpusda dan anak-anak hima."

Dari aspek ini, Perpustakaan Desa Kerano Kuncoro kurang siap untuk penerapan SLiMS karena kemampuan dan jumlah yang terbatas untuk mengelola SLiMS. Aspek sumber daya manusia memegang peranan penting dalam mengembangkan perpustakaan. Sumber daya manusia ini diharapkan dapat melaksanakan tugas dan pekerjaan dengan baik.

\section{b) Kesiapan Perangkat Keras}

Dari aspek ini, Perpustakaan Desa Kerano Kuncoro siap untuk penerapan system otomasi berbasis SLiMS. Perpustakaan Desa Kerano Kuncoro telah memiliki perangkat keras seperti computer, laptop serta printer sehingga penerapan SLiMS dapat dilaksanakan. Ketersediaan perangkat keras ini tidak lepas dari adanya kebijakan untuk pengembangan perpustakaan. Pengadaan dilakukan dengan cara bertahap sehingga dapat memenuhi kebutuhan minimal yang ada di perpustakaan.Keadaan perangkat keras tersebut diperkuat dengan hasil analisis dokumen buku inventaris barang dan observasi di ruangan per- 
pustakaan. Dalam hal pemeliharaan perangkat keras dilakukan oleh petugas perpustakaan dengan memanggil jasa service jika ada kerusakan, karena keterbatasan pengetahuan petugas terkait perangkat keras.

\section{c) Kesiapan Perangkat Lunak}

Perangkat lunak adalah software yang digunakan untuk penerapan SLiMS. Program aplikasi yang digunakan di Perpustakaan Kerano Kuncoro adalah SLiMS Versi 9/ Bulian. Program ini dipilih karena dapat diperoleh dengan gratis sehingga perpustakaan desa tidak perlu mengeluarkan biaya di samping mudah untuk dioperasikan karena sudah dimodifikasi. Hal ini sesuai dengan yang diungkapkan petugas perpustakaan, bahwa:

"Alasan menggunakan senayan karena gratis ya jadi tidak menggunakan biaya, kan ada tuh yang kalo beli sampe 100 jutaan dan kebetulan anak hima punya programnya ya jadi saya minta tolong install kan."

Terkait dengan software yang digunakan, hambatan yang terjadi dalam penerapan program senayan adalah petugas perpustakaan belum menguasai program SLiMS, dikarenakan belum adanya buku panduan dan pelatihan khusus tentang SLiMS hanya diikuti sekali saja.

Dari aspek ini, Perpustakaan Desa Kerano Kuncoro siapuntuk penerapan system otomasi berbasis SLiMS walaupun dalam pengoperasiannya masih belum optimal. Sebuah perpustakaan yang akan menjalankan proses otomasi seharusnya memiliki perangkat lunak sebagai alatbantunya. Dalam hal ini, perpustakaan ini telah menggunakan software Senayanversi 9 sebagai alat bantu untuk mengefisiensikan dan mengefektifkan proses pengelolaan.

\section{d) Kesiapan Jaringan}

Dari aspek ini, Perpustakaan Desa Kerano Kuncoro siap untuk penerapan system otomasi berbasis SLiMS karena sudah adanya wifi walaupun belum terkoneksi ke perpustakaan lainnya.
Hal senada diungkapkan oleh petugas perpustakaan dan kepala perpustakaan bahwa:

"Di perpustakaan ini sudah ada wifi dengan kecepatan 10 Mbps."

"Udah ada wifi ya. Wifinya untuk membantu kerja petugas perpustakaan contohnya akses ke SLiMS ini, pemustaka juga menggunakannya untuk mencari tugas dsb. Jaringannya cuma seperti itu kalo untuk terhubung ke perpus lain belumlah, rencana ada tapi belum tau kapan."

\section{e) Kesiapan Data dan Database}

Dari aspek ini, Perpustakaan Desa Kerano Kuncoro siap untuk penerapan system otomasi berbasis SLiMS walaupun belum maksimal. Data dan database yang dimiliki perpustakaan ini sudah meliputi database koleksi. Dengan adanya database ini akan memudahkan dalam pengolahan koleksi dan melacak koleksi yang ada di perpustakaan.

\section{f) Kesiapan Prosedur}

Prosedur pengaplikasian dan penggunaan SLiMS sangat penting dimiliki oleh perpustakaan untuk mempermudah pelayanannya. Di Perpustakaan Kerano Kuncoro belum ada prosedur penggunaan baik untuk pengguna maupun pengelola perpustakaan, karena keterbatasan pengetahuan petugas. Sesuai dengan yang diungkapkan oleh petugas wawancara, bahwa:

"Untuk prosedurnya apa ya, saya kurang paham. Yang jelas untuk tuntutan kebutuhan apalagi kemarin kan kita ikut lomba perpustakaan desa terbaik dan menggunakan programnya untuk mengikuti perkembangan."

Dari aspek ini, Perpustakaan Desa Kerano Kuncoro kurang siap untuk penerapan sistem otomasi berbasis SLiMS. Prosedur akan membantu petugas perpustakaan serta pengguna dalam penerapan SLiMS. Prosedur merupakan cara 
kegiatan dan tindakan yang akan dapat menerapkan sebuah rencana spesifik/menjalankan sebuah kebijakan. Di perpustakaan ini belum tersedia prosedur yang jelas untuk dapat merefleksikan kebutuhan perpustakaan.

Penerapan sistem otomasi berbasis SLiMS merupakan suatu hal yang memang tidak boleh diabaikan begitu saja, mengingat kemajuan teknologi infomasi yang semakin pesat. Demikian pula kebutuhan pengguna yang haus akan informasi yang up to date terhadap perkembangan ilmu pengetahuan harus diakomodasi oleh perpustakaan dengan menyediakan kemudahan dalam akses dan menemukan informasi.

\section{Kesimpulan dan Saran}

Berdasarkan pembahasan hasil penelitian, dapat diambil kesimpulan bahwa dalam penerapan SLiMS secara garis besar sudah siap, meskipun dari 6 (enam) aspek dalam penerapan sistem otomasi berbasis SLiMS hanya 2 aspek yang masih kurang siap yaitu dalam aspek sumber daya manusia dan aspek prosedur. Sedangkan 4 aspek lainnya siap yaitu aspek perangkat keras, aspekperangkat lunak, jaringan, data dan database.

Saran dari peneliti yang nantinya dapat bermanfaat dalam penerapan SLiMS di Perpustakaan Desa Kerano Kuncoro adalah sebagai berikut:

a. Diharapakan pihak perpustakaan dapat menambah sumber daya manusia yang memiliki latar belakang pendidikan perpustakaan, karena pegawai perpustakaan di perpustakaan Desa Kerano Kuncoro tidak ada yang memiliki latar belakang pendidikan perpustakaan. b. Diharapkan Pihak perpustakaan hendaknya melakukan pelatihan penggunaan SLIMS agar pegawai perpustakaan memahami secara mendalam mengenai aplikasi SLIMS ini, sehingga semua fitur-fitur yang disediakan oleh SLIMS dapatdigunakan dengan maksimal.

c. Diharapkan untuk membuat prosedur pengaplikasian dan penggunaan SLiMS untuk mempermudah pelayanannya.

\section{Referensi}

Arif, Ikhwan. (2013). Makalah seminar dan workshop sehari dengan judul "Membangun jaringan perpustakaan digital dan otomasi menuju masya- rakat berbasis pengetahuan". UMM 4 Oktober 2013. (http:aurajogja. wordpress. com/2006/07/11/otomasi perpustakaan. Didowload pada tanggal 2 Februari 2020).

Fandirwan (2015). Penerapan SLiMS (Senayan Library Management System) Di Perpustakaan AKPER/AKBID Pelamonia Kesdam VII/ Wirabuana Makassar. Makassar: UIN Alauddin.

Mahedy, Kadek Surya (2015). Implementasi Otomasi Layanan Perpustakaan dengan SLiMS Di Perpustakaan UNDIKSHA.

Pendit, Putu L. (2008). Perpustakaan Digital dari A sampai Z. Jakarta: Cipta Karya Karsa.

Rahayuningsih, F. (2007). Pengelolaan perpustakaan. Yogyakarta: Graha Ilmu.

Sulistyo-Basuki. (2017). Pengantar Ilmu Perpustakaan. Jakarta: Gramedia Utama.

Undang-undang No.43 Tahun 2007 tentang Perpustakaan. 